\title{
Angiotensin II influences ovarian follicle development in the transgenic (mRen-2)27 and Sprague-Dawley rat
}

\author{
T E de Gooyer, S L Skinner, M E Wlodek, D J Kelly ${ }^{1}$ and J L Wilkinson-Berka \\ Department of Physiology, The University of Melbourne, Grattan Street, Parkville, Victoria 3010, Australia \\ ${ }^{1}$ Department of Medicine, St Vincent's Hospital, Fitzroy, Victoria 3065, Australia \\ (Requests for offprints should be addressed to J L Wilkinson-Berka, Department of Physiology, Medical Centre, Grattan Street, The University of Melbourne, \\ Parkville, Victoria 3010, Australia; Email: jlaberka@unimelb.edu.au)
}

\begin{abstract}
There is accumulating evidence that local reninangiotensin systems (RASs) influence cell growth and organ function in a variety of tissues including the ovary. The first aim of this study was to characterise the cellular location of RAS components in the rat ovary. This was facilitated by the use of the hypertensive transgenic (mRen-2)27 rat which overexpresses renin and angiotensin in extra-renal tissues. Comparisons were made with normal Sprague-Dawley (SD) rats. The second aim was to determine if the upregulated RAS of the transgenic (mRen-2)27 rat and infusion of angiotensin II (ANG II) in $\mathrm{SD}$ rats influences follicle number and litter size. Gene expression, immunohistochemical and autoradiographic techniques were used to identify a discrete RAS including
\end{abstract}

ANG II receptors in the ovarian stroma, follicles (particularly atretic) and to a lesser extent corpora lutea. The RAS at these sites was most abundant in homozygous (HMZ) followed by heterozygous (HTZ) (mRen-2)27 rats and then SD rats. Large antral and preovulatory follicles and litter size were reduced in (mRen-2) 27 rats. In HMZ (mRen-2)27 rats and SD rats infused with ANG II, angiotensin 1a $\left(\mathrm{AT}_{1 \mathrm{a}}\right)$ receptor mRNA in the ovarian stroma was lower than control SD rats and was associated with a reduction in large antral and preovulatory follicles. These findings indicate that upregulation of the ovarian RAS in the rat influences follicular development and, potentially, reproductive capacity.

Journal of Endocrinology (2004) 180, 311-324

\section{Introduction}

Apart from its role in the regulation of blood pressure and fluid homeostasis, angiotensin II (ANG II) also influences cell growth, angiogenesis and programmed cell death (Fernandez et al. 1985, Daemen et al. 1991, Moravski et al. 2000, Kelly et al. 2002). The cellular effects of ANG II may occur via local production in tissues, as reninangiotensin systems (RASs) have been identified in many organs including the eye (Berka et al. 1995), adrenal (Ryan 1967, Berka et al. 1996), heart (Bohm et al. 1995) and thymus (Wilkinson-Berka et al. 2002). There is also considerable evidence for the existence of local RASs in reproductive tissues such as the uterus (Ryan \& Johnson 1969), testis (Pandey et al. 1984) and placenta (Hodari et al. 1967, Skinner et al. 1968). With regard to the ovary, components of the RAS have been identified in many species, and locally produced ANG II has been suggested to have diverse roles including the modulation of atresia, steroidogenesis, ovulation, oocyte maturation, corpus luteum formation and angiogenesis (Yoshimura 1997, Speth et al. 1999, Vinson et al. 1999). However, some of the actions of ANG II appear contradictory, and as the distribution, abundance and role of the ovarian RAS varies between species, further investigation into the ovarian RAS is justified.

While studies of the rat ovary have provided information regarding the local effects of ANG II (Yoshimura 1997, Speth et al. 1999, Vinson et al. 1999), the characterisation of the rat ovarian RAS has to some extent been limited by the low levels of tissue RAS expression (Phillips et al. 1993). The normal Sprague-Dawley (SD) rat possesses the Ren-1 gene which is responsible for the expression of renin in kidney and low levels of renin in extra-renal tissues (Ekker et al. 1989). To study the role of extra-renal RASs in the development of hypertension, the transgenic (mRen-2)27 rat was developed by the introduction of the murine Ren-2 gene into the genome of the SD rat (Mullins et al. 1990). The hypertensive transgenic (mRen-2)27 rat exhibits amplified circulating prorenin, extra-renal renin and angiotensin at sites where they would normally be expressed in low amounts in the SD rat. This feature has allowed the distribution and function of tissue RASs to be studied in both normal and disease states (Bohm et al. 1995, Kelly et al. 1998, Moravski et al. 2000, 2003, Wilkinson-Berka et al. 2002).

The first aim of the present study was to determine the cellular location of the RAS in the rat ovary. 
The transgenic (mRen-2)27 rat was compared with the normal SD rat. To facilitate identification of the ovarian RAS, (mRen-2)27 rats homozygous (HMZ) for the Ren-2 gene were compared with their heterozygous (HTZ) counterparts. HMZ (mRen-2)27 rats have previously been reported to exhibit higher levels of extrarenal renin and angiotensin and blood pressure than HTZ (mRen-2)27 rats (Bader et al. 1992). The second aim was to determine if amplification of the RAS in the transgenic (mRen-2)27 rat and infusion of ANG II in SD rats influences follicular development and litter size.

\section{Materials and Methods}

\section{Animals}

All experimental procedures adhered to the guidelines of the National Health and Medical Research Council of Australia's Code for the Care and Use of Animals for Scientific Purposes, and were approved by the Bioethics Committee of the University of Melbourne. All rats were housed in a stable environment (maintained at $20 \pm 2{ }^{\circ} \mathrm{C}$ with a $12 \mathrm{~h}$ light: $12 \mathrm{~h}$ darkness cycle) and allowed free access to tap water and standard rat chow (GR2, Clark-King \& Co., New South Wales, Australia). All rats were between 13 and 16 weeks old and a sample size of 6-8 rats per group was used for each of the parameters analysed.

Four groups of rats were studied: group 1, transgenic (mRen-2)27 rats HMZ for the Ren-2 gene; group 2, transgenic (mRen-2)27 rats HTZ for the Ren-2 gene; group 3, control SD rats; and group 4, SD rats infused with ANG II for 12-14 days (SD+ANG II). Transgenic (mRen-2)27 rats HMZ for the Ren-2 gene usually require anti-hypertensive therapy for survival; this was withdrawn from breeding pairs and throughout the entire study. HTZ (mRen-2)27 rats were derived by mating a HMZ male (mRen-2)27 rat with a female SD rat and do not require anti-hypertensive therapy for survival. Transgenic (mRen-2)27 rats were obtained from our breeding colony established in 1996 and SD rats were obtained from the Animal Research Centre (ARC, Canning Vale, Perth, Western Australia, Australia).

In group 4, SD rats were anaesthetised with a mixture of $0.5 \mathrm{mg} / \mathrm{kg}$ medetomidine (Domitor; Novartis Pharma AG, Basel, Switzerland) and $75 \mathrm{mg} / \mathrm{kg}$ ketamine hydrochloride (Ketalar, Parke Davis Pty Ltd, Auckland, New Zealand). A small area of skin at the back of the neck was shaved and Riodine Povidone-Iodine antiseptic solution (Orion Laboratories Pty Ltd, Western Australia, Australia) was liberally applied to the area. A $0.5 \mathrm{~cm}$ incision was made and the skin separated from the superficial fascia by blunt dissection. A mini-osmotic pump (Alzet model 2004, Alza Corporation, Palo Alto, CA, USA) was inserted subcutaneously into a prepared area and the incision closed with several small sutures. Metetomidine anaesthe- sia was reversed using $1 \mathrm{mg} / \mathrm{kg}$ atipamezole hydrochloride (Antisedan; Novartis). The mini-osmotic pumps were filled with $10.4 \mathrm{mg} / \mathrm{ml}$ ANG II dissolved in $0.9 \% \mathrm{NaCl}$, using a 26-gauge needle attached to a $1 \mathrm{ml}$ syringe. Pumps were weighed prior to and after filling to ensure maximum capacity was reached. Mean pump capacity was $99 \pm 4.5 \mu \mathrm{l}$ and the mean pumping rate was $0 \cdot 21 \pm 0 \cdot 01 \mu \mathrm{l} / \mathrm{h}$. Based on an average rat body weight of $250 \mathrm{~g}$, the delivery rate of ANG II was calculated as $145 \mathrm{ng} / \mathrm{kg}$ per min.

\section{Oestrus cycle}

To ensure that the stage of oestrus cycle did not influence the interpretation of results, ovaries were collected at proestrus for in situ hybridisation, immunohistochemistry, renin assay and ANG II receptor and angiotensinconverting enzyme (ACE) autoradiography. Systolic blood pressure (SBP) was measured at proestrus. Oestrus cycle was evaluated by daily histological examination (between 0900 and $1200 \mathrm{~h}$ ) of the vaginal epithelium. Smears obtained by vaginal lavage were stained with Giemsa's stain No. 11 (BDH, Poole, Dorset, UK) and were identified by light microscopy as: proestrus (day 1), oestrus (day 2), diestrus (day 3) or pre-proestrus (day 4). To ensure that the stage of the oestrus cycle did not influence the ovarian and plasma RAS, all rats were killed at the same time of day (1300-1700 h).

\section{Systolic blood pressure}

SBP was recorded prior to tissue collection in pre-warmed conscious rats by tail cuff plethysmography. Arterial pressure changes detected by a Pneumatic Pulse Transducer PE-300 (Narco Biosystems Inc., TX, USA) were recorded using a Chart program (version 3.5) on a Maclab/2E System (AD Instruments Pty Ltd, Australia). SBP was taken at the same time of the day (1400-1700 h) in order to minimise circadian influences from an average of at least three consecutive measurements (Bunag 1973).

The cellular localisation of the ovarian RAS in untreated HTZ and HMZ (mRen-2)27 rats and control SD rats

In situ hybridisation for renin and ANG II receptors At proestrus, (mRen-2)27 and SD rats were anaesthetised with an intraperitoneal injection of pentobarbital sodium (Nembutal, $50 \mathrm{mg} / \mathrm{kg}$ body weight, Boehringer Ingelheim, Australia) and a midline incision made. Ovaries were removed and cleaned of adherent adipose tissue. One ovary was collected from each rat and immersed in Bouins fixative (Pathtec Diagnostics Pty Ltd, Victoria, Australia), routinely processed and embedded in paraffin. Each ovary was serially sectioned at $3 \mu \mathrm{m}$ and placed on $1 \%$ 3-aminopropyltriethoxysilane-coated slides. 
Six randomly chosen sections from one ovary from each rat ( $n=6$ rats per group) were hybridised with $\left[{ }^{33} \mathrm{P}\right] \mathrm{UTP}-$ labelled riboprobes as previously described (Moravski et al. 2000). Riboprobes were prepared from: cDNA encoding mouse renin $(0.525 \mathrm{kbp}$; gift of Dr D J Campbell, St Vincent's Institute of Medical Research, Melbourne, Australia) cloned into pGEM3Z plasmid (Promega) and linearised with HindIII to produce antisense riboprobe using T7 RNA polymerase. pBluescript II KS plasmids (Stratagene, La Jolla, CA, USA) containing cDNA encoding rat $\mathrm{AT}_{1 \mathrm{a}}(2 \cdot 3 \mathrm{kbp})$ or $\mathrm{AT}_{2}(1 \cdot 15 \mathrm{kbp})$ (gift of $\mathrm{Dr} \mathrm{A}$ Allen, Howard Florey Institute, Melbourne, Australia), were linearised with HpaI $\left(\mathrm{AT}_{1 \mathrm{a}}\right)$ or $\mathrm{BamHI}\left(\mathrm{AT}_{2}\right)$, and antisense riboprobes transcribed using the RNA polymerases $\mathrm{T} 3$ and $\mathrm{T} 7$ respectively. After washing to remove unbound probe, sections were exposed to Kodak BioMax autoradiograph film (Kodak) for 7 days. Densitometric analysis of the autoradiographic signal was performed by scanning autoradiograph images using a flat-bed scanner attached to an IBM computer with a $512 \times 512$ pixel array imaging board with 256 grey levels (Moravski et al. 2000). Quantitative measures of the density of digitised autoradiographs were evaluated using an appropriately calibrated Analytical Imaging Station (AIS; Imaging Research, Ontario, Canada). The density of labelling over the area of the entire ovary was quantified as an index of gene expression, and data expressed as relative optical densities (ROD). All analyses were done with the observer masked to the animal study group. To determine the cellular localisation of hybridisation signal, slides were subsequently coated in 50\% LM-1 Amersham Hypercoat liquid emulsion (Amersham) for 28 days, developed, and counterstained with haematoxylin and eosin (Amber Scientific Pty Ltd, Belmont, Western Australia, Australia).

Immunohistochemistry for RAS components Using established methods (Berka et al. 1995, Wilkinson-Berka et al. 2002), randomly chosen $3 \mu \mathrm{m}$ paraffin sections of ovary were incubated with either a polyclonal rabbit anti-rat angiotensinogen antiserum (gift of Dr Conrad Sernia, Department of Physiology and Pharmacology, University of Queensland, Australia) (Sernia et al. 1986), a polyclonal rabbit anti-rat renin antiserum (gift of Dr Joël Ménard, INSERM U367, Paris, France) or a polyclonal guinea-pig anti-human ANG II primary antisera (Peninsula Laboratories Inc., Belmont, CA, USA). Following thorough washing with $0 \cdot 1 \mathrm{M}$ PBS, the sections were incubated with either biotinylated goat anti-rabbit immunoglobulin (for angiotensinogen; Dako Corporation, Carpinteria, California, USA), biotinylated rat anti-rabbit immunoglobulin (for renin; Dako Corporation), or biotinylated goat anti-guinea-pig immunoglobulin (for ANG II; Pierce, Rockford, IL, USA), diluted 1:200 with PBS. To visualise the location of protein immunolabelling, sections incubated with a pre-formed avidin and biotinylated horseradish peroxidase macromolecular complex (diluted 1:200 with 0.1 M PBS; Vectastain Elite ABC Kit, Vector Laboratories Inc., Burlingame, CA, USA) for $30 \mathrm{~min}$, and reacted with 3,3'-diaminobenzidine chromagen solution (DAB; Dako Corporation) diluted in imidazole-HCl buffer (containing hydrogen peroxide, $\mathrm{pH}$ 7-5). Sections were counterstained with Mayer's haematoxylin. Sections incubated with normal serum instead of the primary antibody served as negative controls. Positive controls were liver for angiotensinogen, and juxtaglomerular cells in kidney for renin and ANG II (not shown).

Angiotensin-converting enzyme (ACE) autoradiography One ovary was collected from each rat and embedded using TissueTek OCT embedding compound (Sakura Finetek USA Inc., Torrance, CA, USA) in $25 \mathrm{~mm} \times 20 \mathrm{~mm} \times 5 \mathrm{~mm}$ TissueTek cryomoulds (Miles Inc. Diagnostics Division, Elkhart, IN, USA); ovaries were rapidly frozen by placing them on dry ice. Iodinated MK-351A, a potent competitive inhibitor of ACE, was used to facilitate the autoradiographic localisation of ACE in $20 \mu \mathrm{m}$ frozen sections according to the methodology of Mendelsohn et al. (Mendelsohn 1984). Non-specific binding in parallel sections was assessed in the presence of ${ }^{125}$ I-labelled MK-351A and $1 \mathrm{mM}$ EDTA $(\mathrm{BDH}$ Laboratory Supplies, Poole, UK) which contains zinc residues that bind to the active site of ACE. Sections of rat lung served as positive controls. Tissue sections were washed, dried and exposed to Kodak BioMax autoradiograph film. Densitometric analysis of autoradiographic binding was performed and quantitated as described above for in situ hybridisation. In order to visualise anatomical localisation of binding, sections were first post-fixed overnight in a sealed container with paraformaldehyde powder $(\mathrm{BDH})$, before slides were coated in liquid emulsion for 7 days, developed and counterstained with haematoxylin and eosin.

Ovarian renin content and plasma renin A separate group of rats was used to estimate ovarian renin content and plasma renin. The right ovary from each rat was collected in $300 \mu \mathrm{l}$ of $0.1 \mathrm{M} \mathrm{PBS}(\mathrm{pH} 7 \cdot 4)$ and snap-frozen in liquid $\mathrm{N}_{2}$ for analysis of total renin content using established techniques (Berka et al. 1995, Kelly et al. 1998, Wilkinson-Berka et al. 2001). The left ovary was collected in $300 \mu \mathrm{l}$ of $0 \cdot 1 \mathrm{M}$ PBS (pH 7.4) with protease inhibitors (7.5 mM N-ethylmaleimide, $6 \mathrm{mM}$ disodium ethylenediamine tetraacetic acid and $30 \mathrm{mM}$ benzamidine) and snap-frozen in liquid $\mathrm{N}_{2}$ for analysis of active renin content. Ovaries were stored at $-20{ }^{\circ} \mathrm{C}$ until the day prior to assay, when they were thawed, manually homogenised and refrozen overnight. Blood was collected from the tail vein of conscious animals into a heparinised tube (CSL, Parkville, Victoria, Australia) and subsequently centrifuged at $2000 \boldsymbol{g}$ for $15 \mathrm{~min}$ and plasma was frozen in aliquots at $-20{ }^{\circ} \mathrm{C}$ until analysis. 
The renin content of ovaries and plasma wasanalysed using an ${ }^{125}$ I-labelled ANG I enzyme kinetic radioimmunoassay performed as described previously (Moravski et al. 2000, Wilkinson-Berka et al. 2002). Samples were incubated in duplicate $\left(37^{\circ} \mathrm{C}\right.$ for $\left.0.5-3 \mathrm{~h}, \mathrm{pH} 7 \cdot 4\right)$ in the presence of inhibitors with $24 \mathrm{~h}$ nephrectomised rat plasma angiotensinogen substrate (reaction rate, 70\% maximum velocity). Following the addition of buffered anti-ANG I antiserum (50\% optimum binding capacity) and ${ }^{125}$ I-labelled ANG I tracer $(5000$ c.p.m./ml, Austin Biomedical Services, Malvern, Victoria, Australia), the ANG I produced was estimated from an ANG I standard curve (10-1000 fmol ANG I). The renin present in each of the samples was estimated by comparison to the amount of ANG I generated by $2 \times 10^{-6}$ Goldblatt units (GU) of hog renin (National Standards Laboratory, Holly Hill, London, UK). Tissue values were adjusted based on the initial volume the sample was collected in and normalised for tissue weight. Total renin was determined in samples following activation of prorenin with trypsin $(6 \mathrm{mg} / \mathrm{ml}$ in $1 \mathrm{mM} \mathrm{HCl}$ at $4{ }^{\circ} \mathrm{C}$ for $10 \mathrm{~min}$, reaction stopped with $8 \mathrm{mg} / \mathrm{ml}$ soybean trypsin inhibitor), prior to the commencement of the assay. Prorenin was derived as total minus active renin (samples collected in protease inhibitors).

\section{The effect of ANG II on follicle number and litter size}

Comparisons were made between HTZ and HMZ (mRen-2)27 rats that display amplification of the circulating and extra-renal RAS, control SD rats and SD rats infused with ANG II.

Follicle identification and quantification Using serial sections of ovary collected for in situ hybridisation and immunohistochemistry (see above), every tenth section was stained with haematoxylin and eosin and the number of follicles counted in two randomly chosen sections. This method, which counts approximately $1 \%$ of serial sections, has previously been reported to be comparable to counting $10 \%$ of non-random sections of ovary in mice (Bucci et al. 1997). Low-power images encompassing the entire section were captured using a Spot Digital Camera (SciTech Pty Ltd, Victoria, Australia) attached to an Olympus BH-2 Light Microscope (Olympus, Japan). Images were examined using ImagePro Plus software (v. 4.0.0.13; Media Cybernetics L.P., Singapore) and follicle diameter (in $\mu \mathrm{m}$ ) measured on a calibrated system. Follicle diameter was determined as the average of the distance of the longest follicle axis and the length of the perpendicular axis. Follicles were classified into one of five size groups; primary $(<80 \mu \mathrm{m}), \quad$ pre-antral $(80-150 \mu \mathrm{m}), \quad$ antral $(150-390 \mu \mathrm{m})$, large antral $(390-500 \mu \mathrm{m})$ or preovulatory $(>500 \mu \mathrm{m})$ (Hirshfield \& Midgley 1978). A follicle was considered to be undergoing atresia when a minimum of two pyknotic granulosa cells was observed in the cross-section of a follicle (Hirshfield \& Midgley 1978), or if they contained an abnormal-shaped oocyte or the granulosa cells were not regularly apposed with the basal lamina (Wulff et al. 2001). Analysis was completed with the observer masked to all groups. Data were represented as a percentage of a follicle type when compared with the number of follicles per section.

Litter size The number of pups born to SD dams crossed with SD males, and HMZ dams crossed with HMZ males was determined ( $n=15$ pups per strain). The number of HTZ (mRen-2)27 pups was not recorded as they are not derived from transgenic (mRen-2)27 mothers but from matings of female SD rats with male transgenic (mRen-2)27 rats. As the ANG II infusion study was performed in non-pregnant adult SD rats, the effect of ANG II on litter size in these animals could not be evaluated.

\section{Verification that ANG II infusion in SD rats per-} turbs the circulating and ovarian RAS This was done in two ways: (i) evaluation of angiotensin receptor gene expression in the ovary using in situ hybridisation (see aim 1 of the study) and (ii) evaluation of the circulating and ovarian renin levels using an enzyme kinetic renin assay (see $\operatorname{aim} 1)$.

\section{Statistical analysis}

Statistical computations were performed using the commercially available statistics package SPSS (version 9.0; SPSS Inc., Chicago, IL, USA). Results are expressed as means \pm S.E.M. Data were analysed using ANOVA when there were three or more groups with post-hoc analysis between groups made using Fisher's multiple comparisons test. Statistical comparison of data between two groups was made using a $t$-test for independent samples. Analysis of differences between two variables measured in the same group was made using a $t$-test for paired samples. A $P$ value less than 0.05 was considered statistically significant.

\section{Results}

\section{Systolic blood pressure}

SBP was significantly higher in HMZ (mRen-2)27 rats (234 $\pm 5 \mathrm{mmHg}, n=8)$ compared with HTZ (mRen-2)27 rats $(171 \pm 3 \mathrm{mmHg}, n=8 ; P<0 \cdot 001)$. Both HTZ and HMZ (mRen-2)27 rats displayed higher SBP than control $\mathrm{SD}$ rats $(126 \pm 1 \mathrm{mmHg}, n=8 ; P<0 \cdot 001)$. SD rats treated with ANG II exhibited increased blood pressure $(183.2 \pm 9.5 \mathrm{mmHg}, n=8 ; \quad P<0.001)$ compared with untreated SD rats that was similar to HTZ (mRen-2)27 rats but less than HMZ (mRen-2)27 rats $(P<0 \cdot 005)$. 
Table 1 A summary of the distribution and intensity of renin, $\mathrm{AT}_{1 \mathrm{a}}$ and $\mathrm{AT}_{2}$ receptors, $\mathrm{ANG}$ II, angiotensinogen and ACE in the ovaries of control SD rats and HTZ and HMZ transgenic (mRen-2)27 rats

\begin{tabular}{|c|c|c|c|}
\hline & SD & HTZ (mRen-2)27 & HMZ (mRen-2)27 \\
\hline & Stroma & Stroma & Stroma \\
\hline Renin mRNA & ND & ++ & +++ \\
\hline Renin protein & + & ++ & ++ \\
\hline $\mathrm{AT}_{1 \mathrm{a}}$ & ++ & ++ & + \\
\hline $\mathrm{AT}_{2}$ & ND & ND & ND \\
\hline ANG II & + & ++ & +++ \\
\hline Angiotensinogen & + & + & + \\
\hline ACE & ++ & +++ & $\mathrm{NE}$ \\
\hline & Follicles & Follicles & Follicles \\
\hline Renin mRNA & ND & ++ (nearly all) & +++ (nearly all) \\
\hline Renin protein & ND & ND & ND \\
\hline $\mathrm{AT}_{1 \mathrm{a}}$ & ND & ND & ND \\
\hline $\mathrm{AT}_{2}$ & $+++($ atretic $)$ & $+++($ atretic $)$ & $++($ atretic $)$ \\
\hline ANG II & + (mostly atretic) & ++ (mostly atretic) & +++ (mostly atretic) \\
\hline Angiotensinogen & $+++($ developing $)$ & +++ (developing) & +++ (developing) \\
\hline $\mathrm{ACE}$ & ++ & +++ & $\mathrm{NE}$ \\
\hline & Corpora lutea & Corpora lutea & Corpora lutea \\
\hline Renin mRNA & ND & ND & $\mathrm{ND}$ \\
\hline Renin protein & ++ & +++ & +++ \\
\hline $\mathrm{AT}_{1 \mathrm{a}}$ & ND & ND & ND \\
\hline $\mathrm{AT}_{2}$ & ND & ND & ND \\
\hline ANG II & + & ++ & +++ \\
\hline Angiotensinogen & ++ & ++ & ++ \\
\hline ACE & ++ & ++ & NE \\
\hline
\end{tabular}

$\mathrm{ND}$, not detected; $\mathrm{NE}$, not evaluated; + , weak signal; ++ , moderate signal; +++ , intense signal.

The cellular location of RAS components in the rat ovary

These results are summarised in Table 1.

\section{Renin gene expression and immunolabelling}

Renin mRNA was not detected in ovaries from control SD rats (Fig. 1A). In HTZ and HMZ (mRen-2)27 rats, renin mRNA was present in the stroma (Fig. 1B), in the theca of nearly all follicles (Fig. 1B) and in the thick granulosa layer of some large antral follicles (not shown). In all (mRen-2)27 rats, renin gene expression was not observed in corpora lutea. Quantification revealed the intensity of renin $\mathrm{mRNA}$ to be higher in ovaries of $\mathrm{HMZ}$ (mRen-2)27 rats compared with HTZ (mRen-2)27 rats and to be virtually undetected in control SD rats (Fig. 1).

In control SD rats and (mRen-2) 27 rats, renin protein immunolabelling was identified in cells and some blood vessels of corpora lutea (Fig. 1C) and to a lesser extent in the ovarian stroma (not shown). Renin protein immunolabelling appeared more intense in HTZ (mRen-2)27 (Fig. 1D) and HMZ (mRen-2)27 rat ovary compared with control SD rats (Fig. 1C).

\section{Angiotensin receptor gene expression}

$\mathrm{AT}_{1}$ a mRA was primarily located on clusters of small blood vessels in the ovarian stroma and adjacent to corpora lutea and large follicles (Fig. 2A and B). The abundance of $\mathrm{AT}_{1 \mathrm{a}}$ receptor mRNA in whole ovary was highest in control SD rats followed by HTZ and then HMZ (mRen-2)27 rats, a finding confirmed by densitometric analysis (Fig. 2). $\mathrm{AT}_{2}$ mRNA was localised to the granulosa layer of small- to medium-sized antral follicles exhibiting signs of atresia in both (mRen-2)27 and SD ovaries (Fig. 2E-H). $\mathrm{AT}_{2}$ receptor $\mathrm{mRNA}$ at these sites was lower in HMZ (mRen-2)27 ovaries when compared with control SD and HTZ (mRen-2)27 rats (Fig. 2). No differences were observed between control SD and HTZ (mRen-2)27 rats in the distribution or intensity of $\mathrm{AT}_{2}$ receptor mRNA (Fig. 2). Verification that ANG II infused into $\mathrm{SD}$ rats altered the ovarian RAS was shown by reduced $\mathrm{AT}_{1 \mathrm{a}}$ receptor $\mathrm{mRNA}$ compared with control SD rats (Fig. 2D). Gene expression for the $\mathrm{AT}_{2}$ receptor was unchanged following ANG II infusion in SD rats compared with control SD rats (Fig. 2H).

\section{Angiotensin II immunolabelling}

In all rat strains, ANG II was localised to the ovarian stroma and its blood vessels (Fig. 3A-C), atretic follicles (Fig. 3D-F), corpus luteum cells and blood vessels (Fig. 3G-I) and granulosa cells particularly at the antral edge of some follicles (not shown). ANG II 


\section{Renin gene expression}
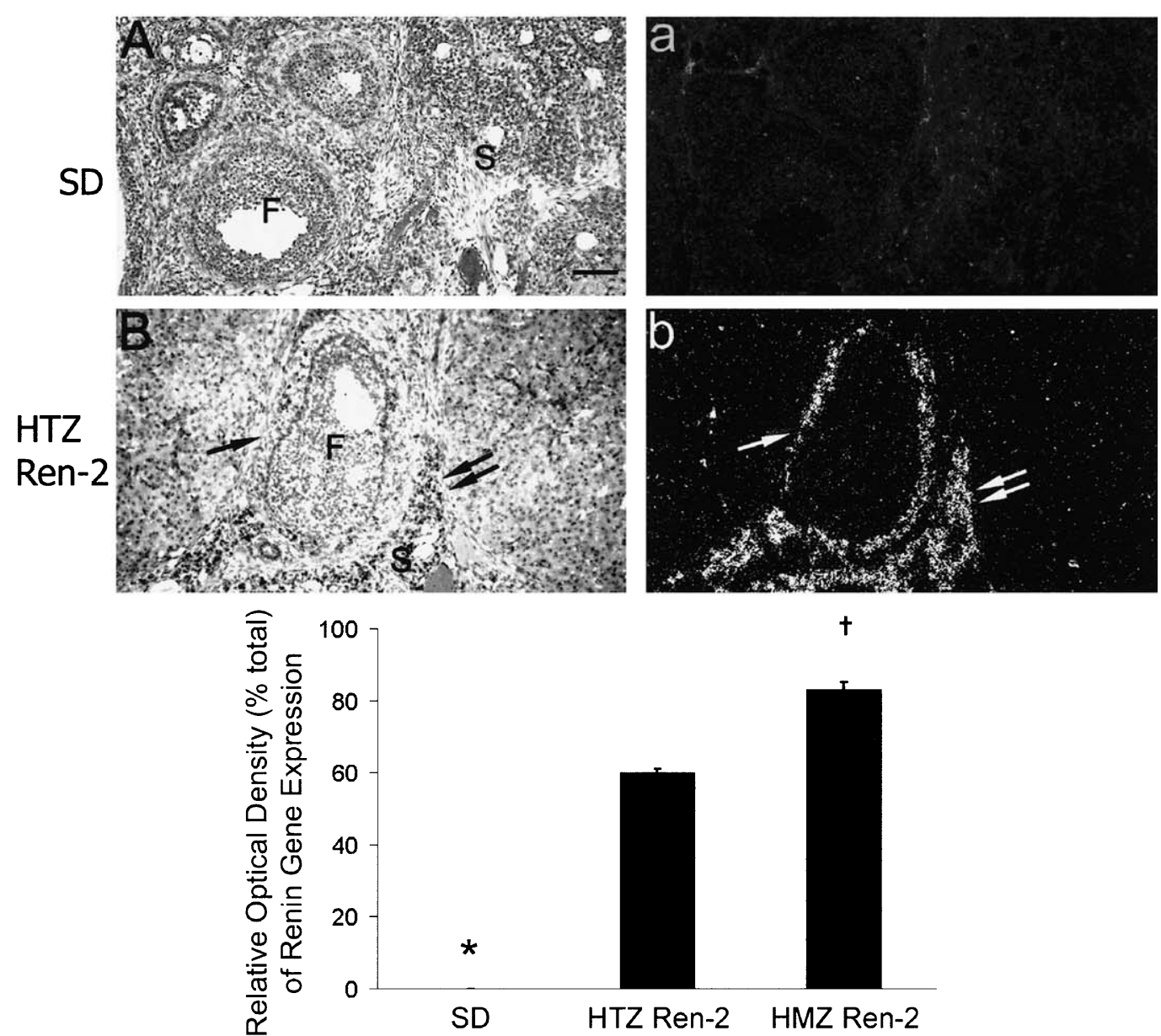

$+$

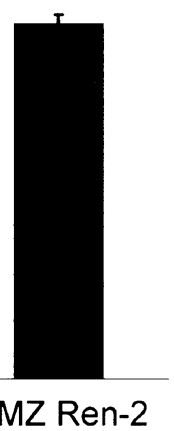

\section{Renin protein immunolabelling \\ SD HTZ Ren-2}
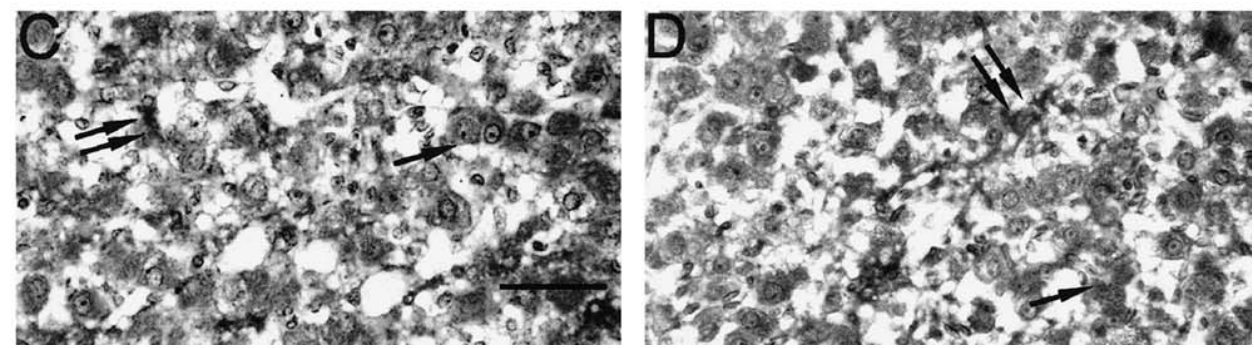

Figure 1 Paraffin sections $(3 \mu \mathrm{m})$ showing renin gene expression and renin protein immunolabelling in ovaries from control SD rats and HTZ and HMZ transgenic (mRen-2)27 rats at proestrus. The graph shows quantification of renin gene expression in sections of whole ovary. (A and B) Magnification, $\times 300$; counterstain, haematoxylin and eosin; scale bar, $100 \mu \mathrm{m}$. (C and D) Magnification, $\times 500$;

counterstain, haematoxylin; scale bar, $50 \mu \mathrm{m}$. S, stroma; F, follicle; Ren-2, transgenic (mRen-2)27 rat. Renin gene expression: bright field (A) and corresponding dark field (a) of control SD ovary, renin gene expression is not observed; bright field (B) and corresponding dark field (b) of HTZ (mRen-2)27 ovary, renin gene expression localised to the stroma (double arrow) and theca (arrow), ${ }^{*}<<0 \cdot 0001$ compared with all (mRen-2) 27 rats, $+P<0.05$ compared with HTZ (mRen-2)27 rats. Renin protein immunolabelling: intense immunolabelling appears in corpus luteum cells (arrow) and blood vessels (double arrow) of control SD (C) and HTZ (mRen-2)27 (D) rats. 


\section{AT1a receptor mRNA}

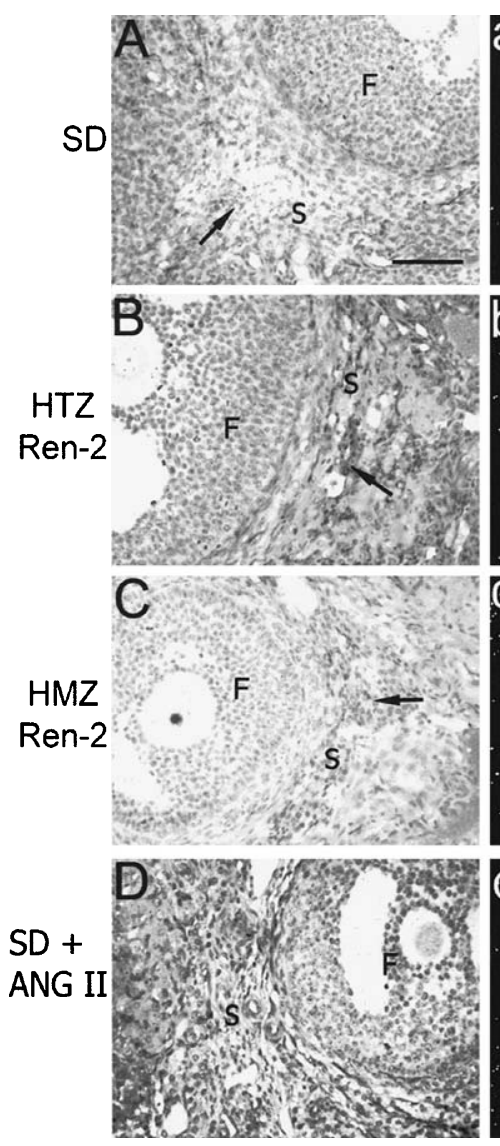

AT1a receptor

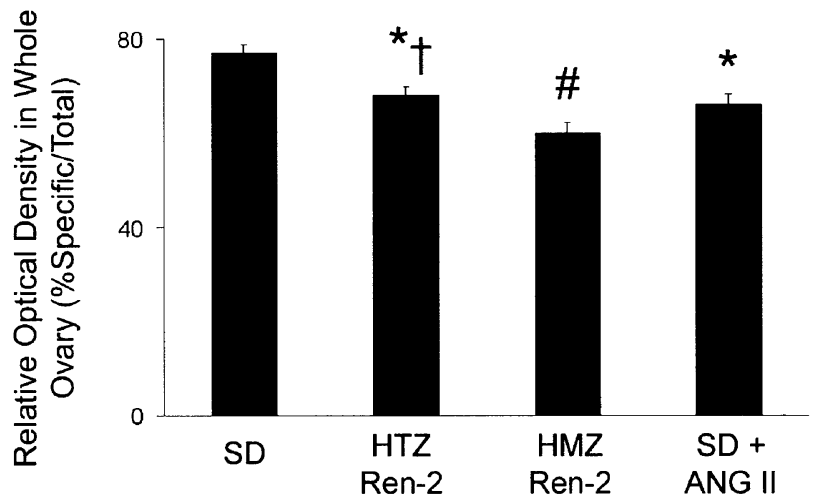

$\mathrm{AT} 2$ receptor $\mathrm{mRNA}$
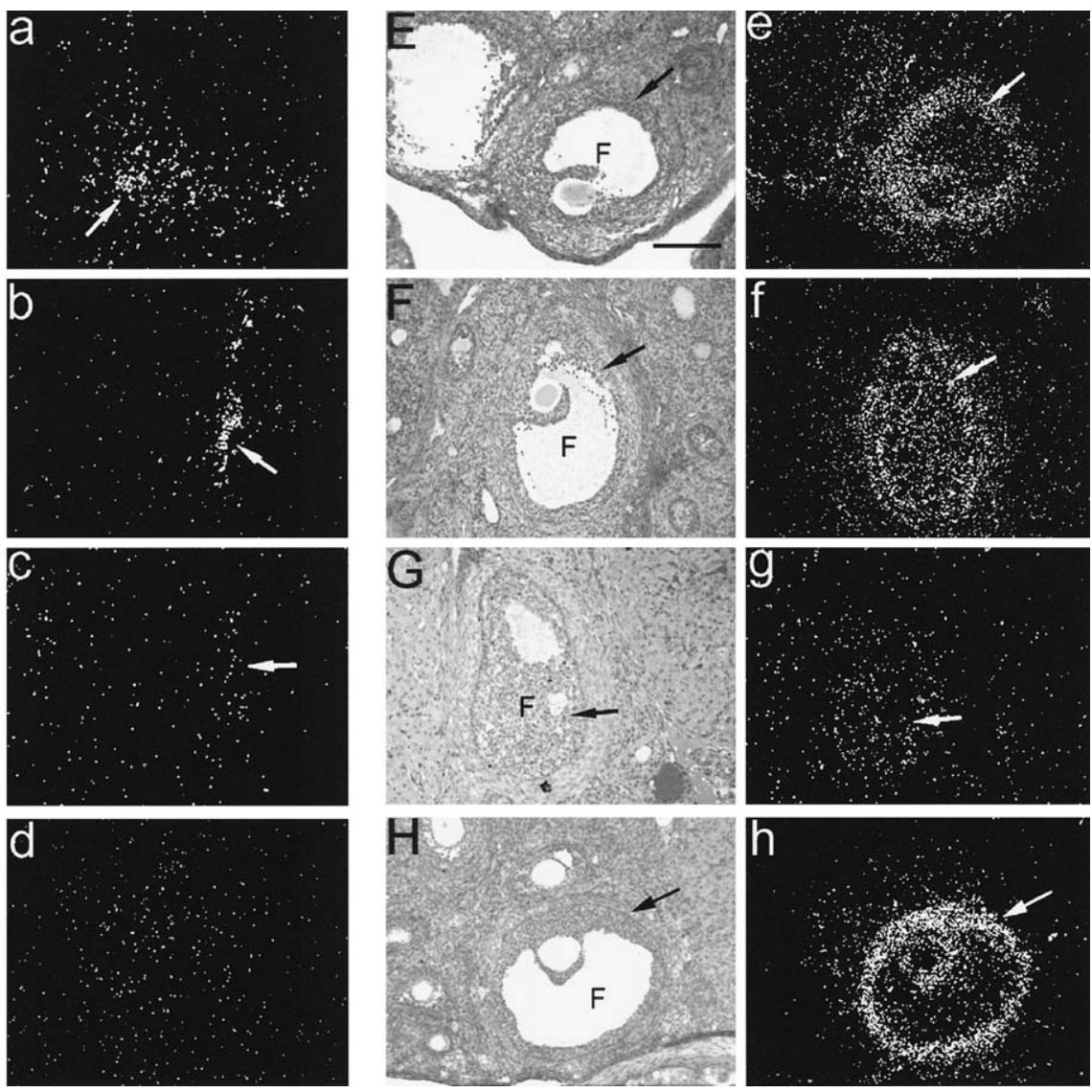

AT2 receptor

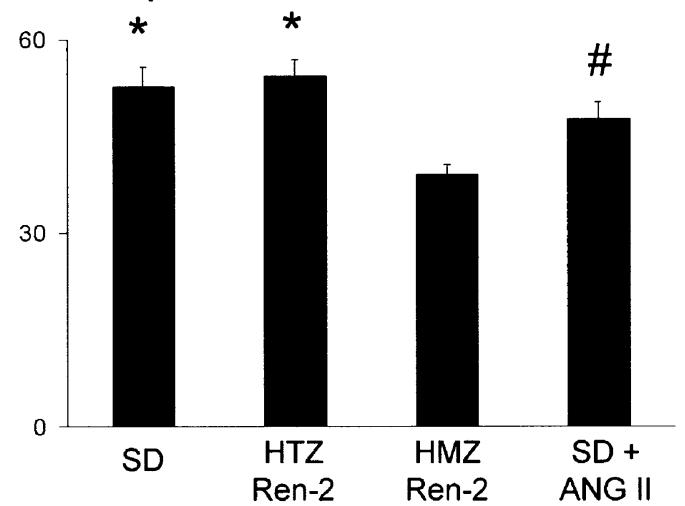

Figure 2 Paired bright $(\mathrm{A}-\mathrm{H})$ and dark $(\mathrm{a}-\mathrm{h})$ field photomicrographs showing the localisation of $\mathrm{AT}_{12}$ and $\mathrm{AT}_{2}$ receptor mRNA in $3 \mu \mathrm{m}$ paraffin sections of control SD rat and HTZ and HMZ (mRen-2)27 rat ovaries at proestrus. The graph depicts quantification of the optical density of $\mathrm{AT}_{12}$ and $\mathrm{AT}_{2}$ receptor gene expression in sections of whole ovary. (A-C) Magnification, $\times 450$; scale bar, $50 \mu \mathrm{m}$. (D-f) Magnification $\times$ 300; scale bar, $100 \mu \mathrm{m}$; counterstain, haematoxylin and eosin. S, stroma; F, follicle; Ren-2, transgenic (mRen-2)27 rat. $\mathrm{AT}_{1 \mathrm{a}}$ receptor mRNA in stroma (arrows) of control SD (A and a), HTZ (mRen-2)27 (B and b), HMZ (mRen-2)27 (C and c) and SD+ANG II ( $D$ and d) ovary: hybridisation is more intense in SD and HTZ (mRen-2)27 ovaries compared with other groups. $\mathrm{AT}_{2}$ receptor mRNA in granulosa cell layer of atretic follicles (arrows) of control SD (E and e), HTZ (mRen-2)27 (F and f) and HMZ (mRen-2)27 (G and g) and SD+ANG II (H and h) ovary: hybridisation is intense in all groups except HMZ (mRen-2)27. Graphical data are presented as means \pm S.E.M.; $n=6$ rats per group. For the $\mathrm{AT}_{1 \mathrm{r}}$ receptor: ${ }^{*} P<0.05$ compared with control SD; ${ }^{\#} P<0 \cdot 0001$ compared with control SD; $+P<0.05$ compared with HMZ (mRen-2)27. For the $\mathrm{AT}_{2}$ receptor: ${ }^{*} P<0 \cdot 0001$ compared with $\mathrm{HMZ}$ (mRen-2)27; $\# P<0 \cdot 05$ compared with HMZ (mRen-2)27. 
ANG II immunolabelling
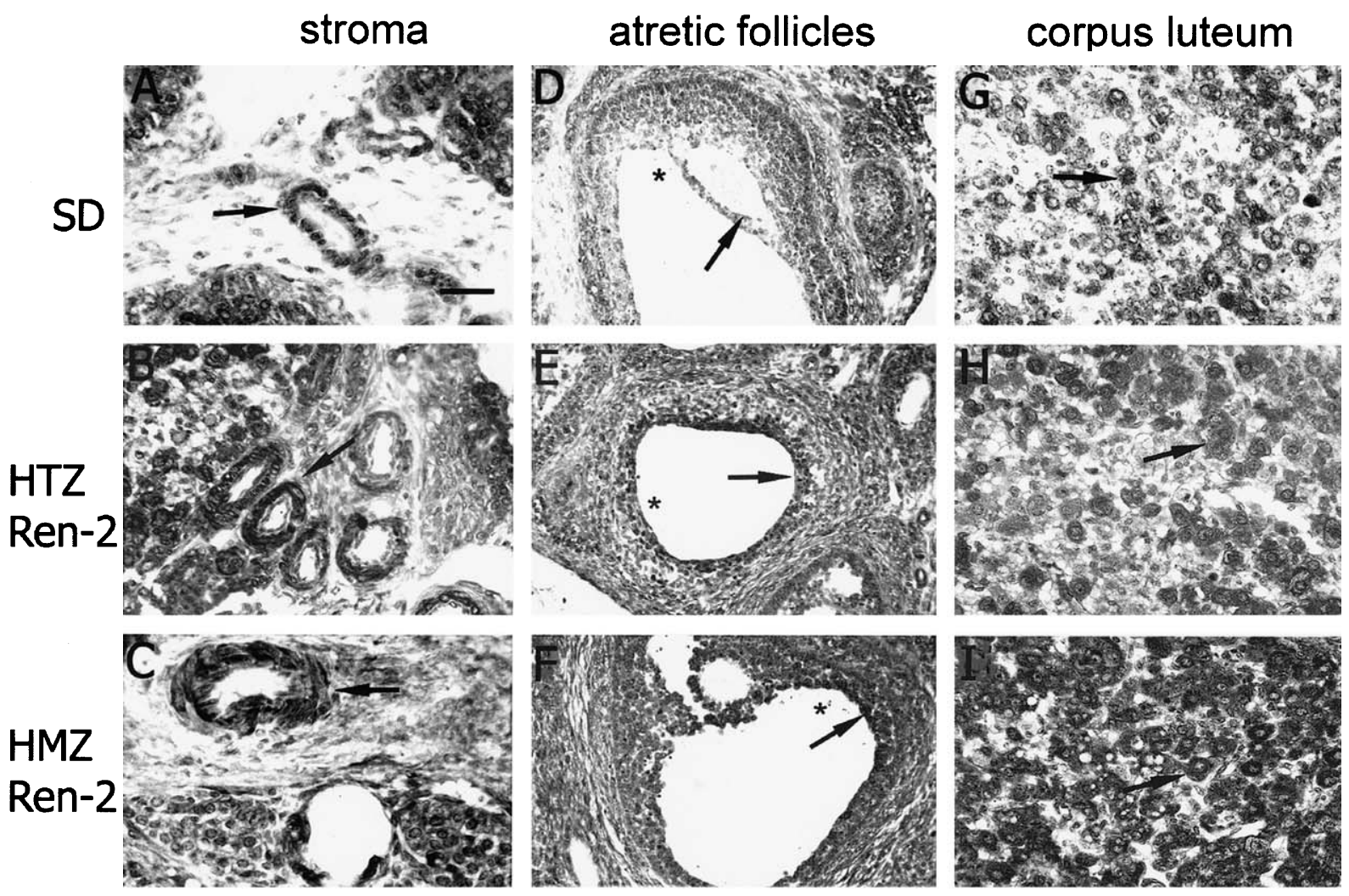

\section{Angiotensinogen immunolabelling \\ SD \\ HTZ Ren-2}
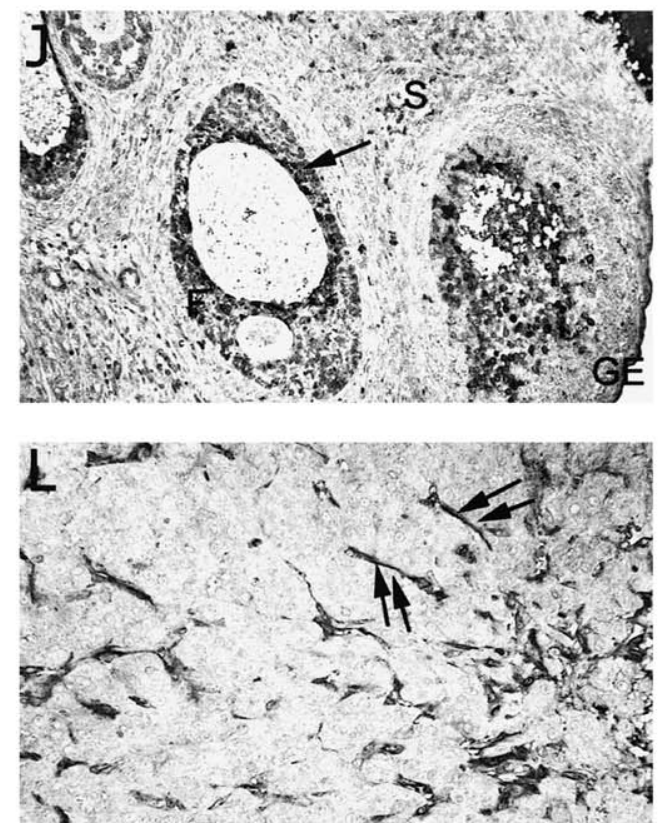
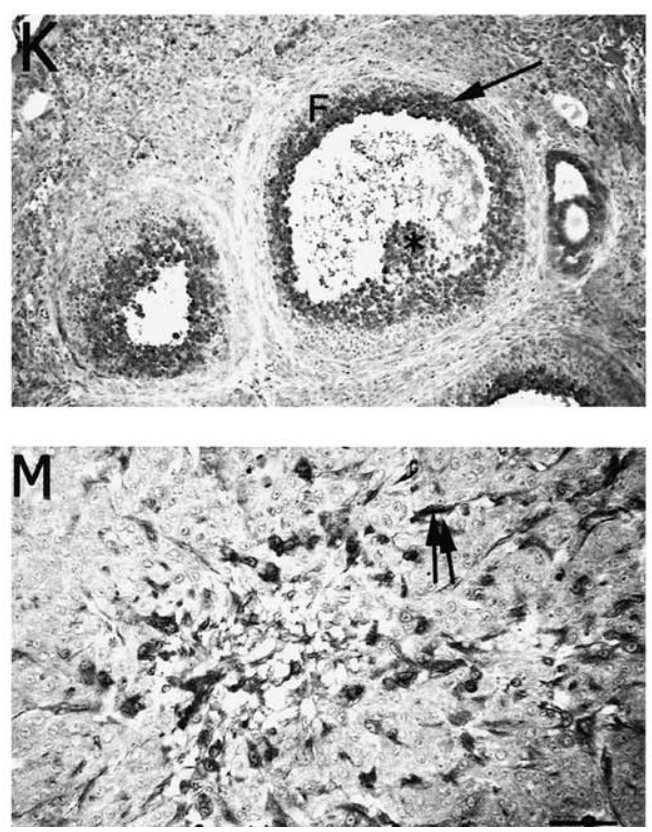
immunolabelling appeared most intense in ovaries of HMZ (mRen-2)27 rats followed by HTZ (mRen-2)27 and then control SD rats.

\section{Angiotensinogen immunolabelling}

The distribution and intensity of angiotensinogen immunolabelling was similar in control SD, HTZ (mRen-2)27 and HMZ (mRen-2)27 ovaries (Fig. 3J-M). Angiotensinogen immunolabelling was prominent in the granulosa layer of developing follicles, particularly in cells adjacent to the follicular fluid, the follicular fluid itself and the cumulus oophorus (Fig. 3J and $\mathrm{K}$ ). Labelling was also observed in some blood vessels in corpora lutea (Fig. 3L and $\mathrm{M}$ ), in the germinal epithelium and in some scattered stromal cells (Fig. 3J and K).

\section{ACE autoradiography}

${ }^{125}$ I-labelled MK-351A binding to cellular ACE appeared to be more intense in the ovaries of HTZ (mRen-2)27 rats compared with control SD rats (Fig. 4A and E). HMZ (mRen-2)27 rats were not studied. Light microscopy examination of emulsion autoradiography revealed ACE ligand binding (Fig. 4C, D, G and $\mathrm{H}$ ) to be located in the ovarian stroma including blood vessels, on the germinal epithelium, in the cell layer surrounding corpora lutea and on some follicles. Quantification of the density of ${ }^{125}$ I-labelled MK-351A binding to cellular ACE in whole ovary was significantly higher $(P<0 \cdot 05)$ in HTZ (mRen-2)27 rats (61.9 $\pm 0.5 \mathrm{ROD}$, mean \pm S.E.M.) compared with SD ovaries $(59 \cdot 1 \pm 0 \cdot 8$ ROD, mean \pm S.E.M. $)$. Non-specific binding was negligible in all sections (Fig. 4B and F).

\section{Plasma renin and ovarian renin content}

Plasma renin As expected for (mRen-2)27 rats with overexpression of the extra-renal RAS (Mullins et al. 1990), plasma renin was predominately prorenin (Fig. 5A). Plasma prorenin was highest in HMZ (mRen-2)27 rats followed by HTZ (mRen-2)27 rats and then control SD rats and SD rats infused with ANG II. In control SD rats, plasma renin was mainly in an active form (Fig. 5A). Plasma active renin was highest in control SD rats followed by HMZ (mRen-2)27 rats, HTZ (mRen-2)27 rats and then SD rats infused with ANG II. The infusion of ANG II into SD rats reduced plasma active renin.
Ovarian renin content In all rats, ovarian renin was mainly in an active form. Ovarian active renin was highest in HMZ (mRen-2)27 rats, followed by HTZ (mRen-2)27 rats, control SD rats and then SD rats infused with ANG II. In SD rats, ovarian active renin content was reduced with ANG II infusion. Ovarian prorenin was similar between all groups except for HTZ (mRen-2)27 rats where ovarian prorenin content was less than in $\mathrm{SD}$ rats infused with ANG II.

\section{Litter size}

Fewer pups per litter were born to HMZ (mRen-2)27 rats $(8 \cdot 7 \pm 0 \cdot 7)$ than control SD rats $(13 \cdot 0 \pm 0 \cdot 4), P<0 \cdot 05$.

\section{Follicle quantification}

At proestrus, all groups had similar numbers of primary follicles (control SD, 18.4 $\pm 5 \cdot 1$; HTZ (mRen-2)27, 10·4 \pm 3·9; HMZ (mRen-2)27, 11·1 $\pm 2 \cdot 3$; SD+ANG II, $21 \cdot 2 \pm 3 \cdot 9)$. Pre-antral follicles were more abundant in HMZ (mRen-2)27 rats compared with all other groups (control SD, 19.4 $\pm 2 \cdot 9$; HTZ (mRen-2)27, 24.2 $\pm 1 \cdot 1$; HMZ (mRen-2) 27, 33·8 $\pm 3 \cdot 3$; SD+ANG II, $23 \cdot 6 \pm 2 \cdot 4$; $P<0 \cdot 05)$. The number of antral follicles was similar between all groups (control SD, 37.5 $\pm 4 \cdot 5$; HTZ

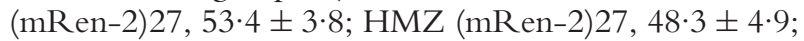
SD+ANG II, 48.5 $\pm 5 \cdot 5)$. Compared with control SD rats, fewer large antral and preovulatory follicles were observed in HTZ (mRen-2)27, HMZ (mRen-2)27 and SD rats infused with ANG II (Fig. 6).

\section{Discussion}

The present study has localised components of the RAS to three distinct compartments within the rat ovary, namely the stroma, follicles (mainly atretic) and to a lesser extent corpora lutea. The presence of angiotensin receptors within the stroma and atretic follicles indicates that the RAS at these sites is likely to have a functional role. In general, components of the RAS were in the same location but more abundant in transgenic (mRen-2)27 rats compared with SD rats, highlighting the usefulness of the (mRen-2)27 rat, with its enhanced extra-renal RAS, for detecting and studying the ovarian RAS. The increased expression of the ovarian RAS in (mRen-2)27 rats was

\footnotetext{
Figure 3 Paraffin sections $(3 \mu \mathrm{m})$ showing ANG II and angiotensinogen immunolabelling in ovaries from SD rats and HTZ and HMZ transgenic (mRen-2) 27 rats at proestrus. (A-I) Magnification, $\times 450$; scale bar, $50 \mu \mathrm{m}$. (J-M) Magnification, $\times 300$; scale bar, $100 \mu \mathrm{m}$; counterstain, haematoxylin. S, stroma; F, follicle; GE, germinal epithelium; Ren-2, transgenic (mRen-2)27 rat. ANG II immunolabelling: in stroma (A, B and C), immunolabelling is observed in blood vessels (arrow) and stromal cells; in atretic follicles (D, E and F), immunolabelling is observed in granulosa cells (arrow), asterisk indicates pyknotic nuclei; in corpora luteum (G, H and I), immunolabelling is in corpus luteum cells (arrow). Angiotensinogen immunolabelling: in follicles ( $\mathrm{J}$ and $\mathrm{K}$ ), immunolabelling is located in the granulosa layer (arrow) and cumulus oophorus (asterisk); in corpora luteum ( $\mathrm{L}$ and $\mathrm{M})$, immunolabelling is on blood vessels (double arrow).
} 


\section{SD $\quad$ ACE binding}
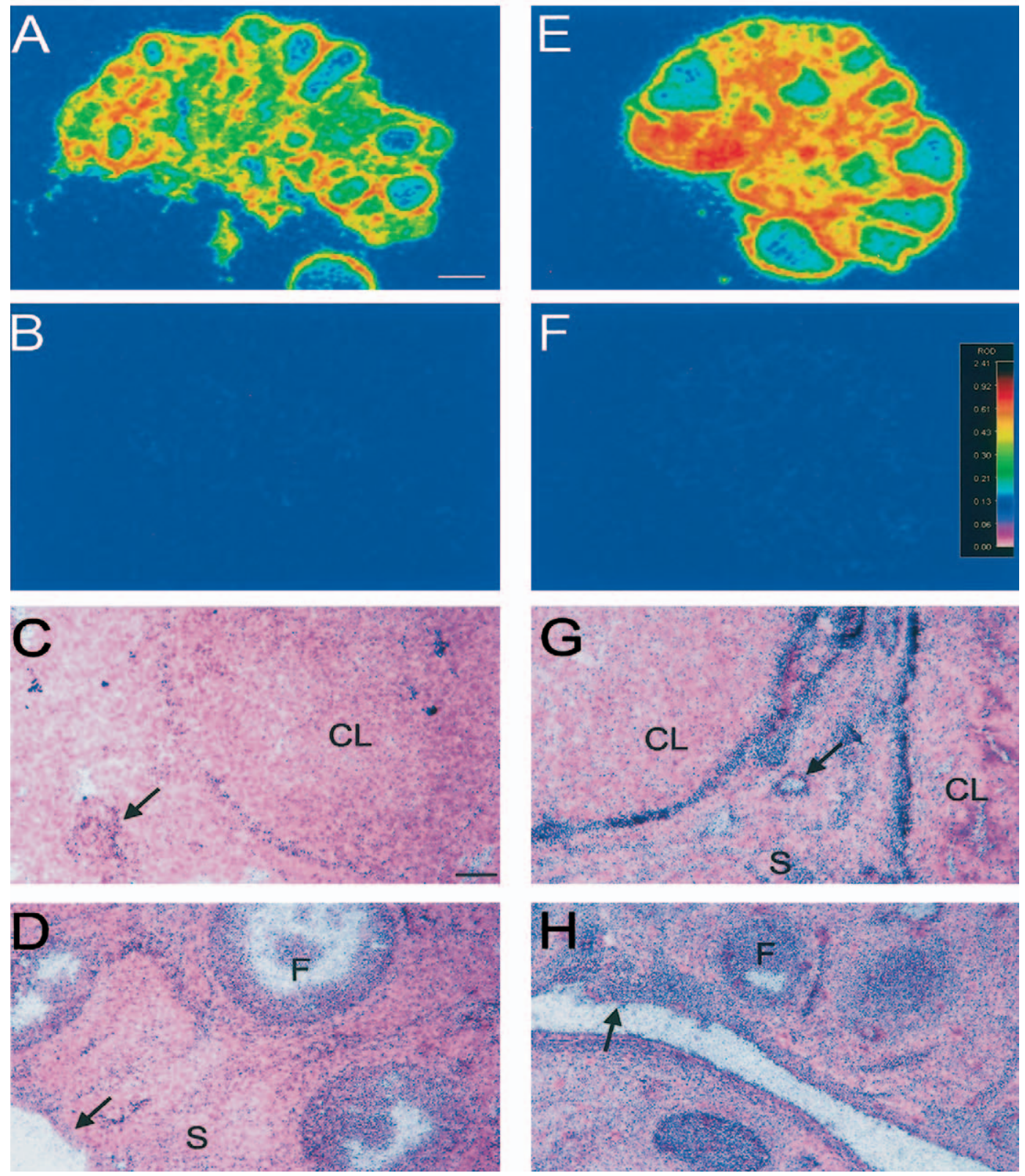

Figure 4 Localisation of binding of ${ }^{125}$ I-labelled MK-351A by ACE in control SD rats and HTZ (mRen-2) 27 rats on autoradiographs of whole ovary and $20 \mu \mathrm{m}$ frozen sections. (A, B, E and F) Autoradiographs; magnification, $\times$ 40; scale bar, $1000 \mu \mathrm{m}$. Scale of relative optical density indicates most intense binding as black and red and least intense binding as blue. $(\mathrm{C}, \mathrm{D}, \mathrm{G}$ and $\mathrm{H})$ Frozen sections; magnification, $\times 450$; scale bar, $150 \mu \mathrm{m}$; counterstain, haematoxylin and eosin. S, stroma; CL, corpus luteum; F, follicle; Ren-2, transgenic (mRen-2)27 rat. (A) SD ovary. (B) SD non-specific binding. (C) SD, ACE localised to cell layer surrounding CL and on blood vessels in stroma (arrow). (D) SD ovary, ACE binding in follicle and on germinal epithelium (arrow). (E) HTZ (mRen-2)27 ovary. (F) HTZ (mRen-2)27 non-specific binding. (G) HTZ (mRen-2)27, ACE binding localised to cell layer surrounding CL and on blood vessels in stroma (arrow). (H) HTZ (mRen-2)27, ACE binding in follicle and on germinal epithelium (arrow). Not analysed in HMZ (mRen-2)27 ovaries. 


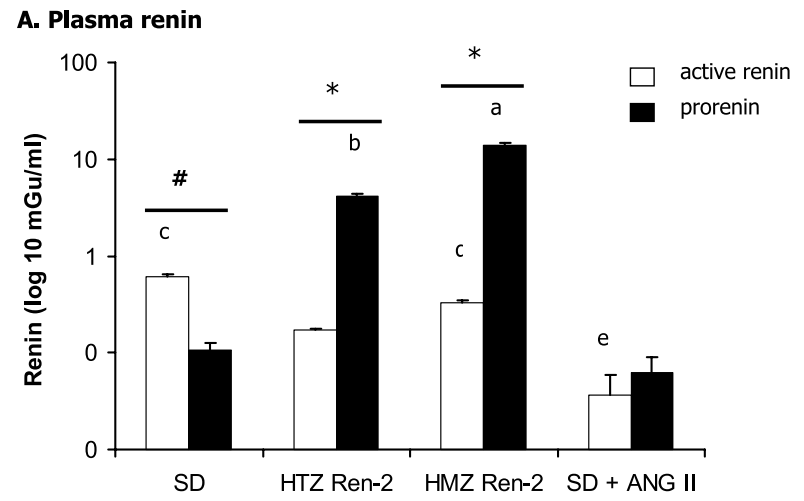

B. Ovarian renin content

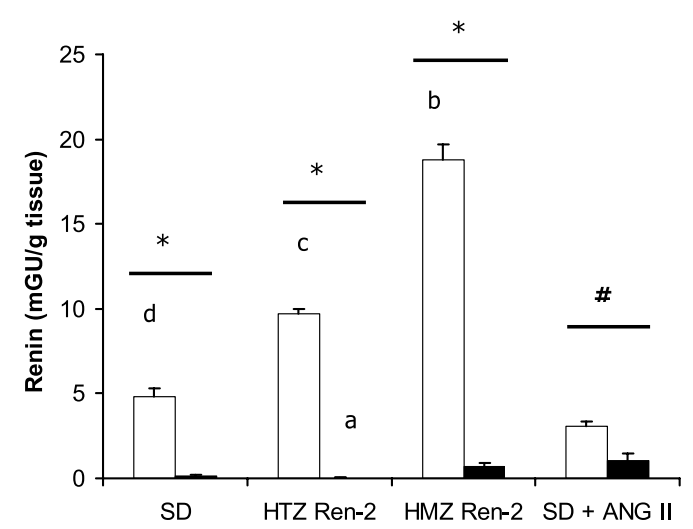

Figure 5 Plasma renin $(A)$ and ovarian renin content $(B)$ in $S D$ rats and HTZ and HMZ (mRen-2)27 rats at proestrus. Data are presented as means \pm S.E.M.; $n=6$ rats per group. GU, Goldblatt units; Ren-2, transgenic (mRen-2)27 rat. (A) Plasma; ${ }^{\star} P<0 \cdot 001$ compared with respective active renin; $\# P<0.005$ compared with respective prorenin. Prorenin: a, $P<0.0001$ compared with all groups; $b, P<0.05$ compared with control $\mathrm{SD}$ and $P<0.01$ compared with SD+ANG II. Active renin: $c, P<0.0001$ compared with all groups; d, $P<0.005$ compared with HTZ (mRen-2)27 rats; e, $P<0.001$ compared with all (mRen-2) 27 rats. (B) Ovarian renin content; ${ }^{*} P<0 \cdot 0001$ compared with respective prorenin; $\# P<0.005$ compared with respective prorenin. Prorenin: a, $P<0.05$ compared with SD+ANG II. Active renin: $b, P<0.0001$ compared with all groups; $c, P<0.005$ compared with $\mathrm{SD}$ and $P<0.0001$ compared with SD+ANG II; $d, P<0.05$ compared with SD+ANG II.

associated with both reduced litter size and numbers of large antral and preovulatory follicles. A similar situation was found in SD rats infused with ANG II, indicating that increased ANG II may influence follicular development.

Considerable species differences exist with regard to the distribution and relative abundance of components of the RAS in the ovary. Previous studies in the rat have identified RAS components in various areas of the ovary (Kim et al. 1987, Daud et al. 1990, Thomas \& Sernia 1990, Obermuller et al. 1998), but to our knowledge none have provided a consistent survey of the ovarian RAS in the rat in situ. The present study identified a discrete RAS within

\section{A. Large antral follicles}

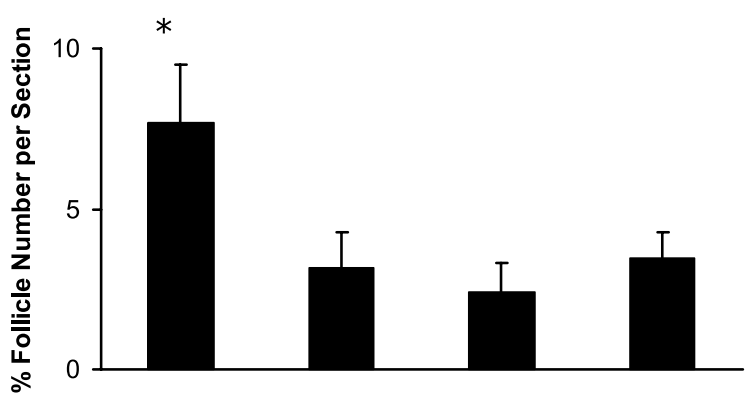

\section{B. Pre-ovulatory follicles}

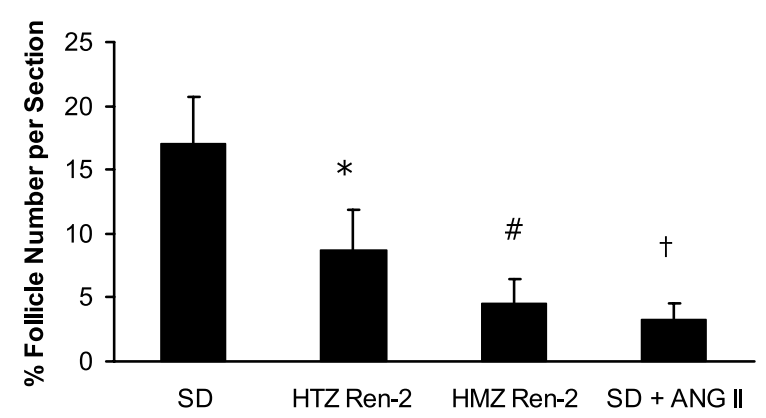

Figure 6 The number of large antral $(A)$ and pre-ovulatory (B) follicles in $3 \mu \mathrm{m}$ sections of ovary from control SD rats, HTZ and HMZ transgenic (mRen-2)27 rats and SD rats infused with ANG II. Data are presented as means \pm S.E.M.; $n=6$ rats per group. Ren-2, transgenic (mRen-2)27 rat. (A) Large antral follicles: ${ }^{\star} P<.005$ compared with all groups. (B) Pre-ovulatory follicles: ${ }^{*} P<0.01$ compared with control SD rats; $\# P<0.0005$ compared with control SD rats; $\uparrow P<0.0001$ compared with control SD rats.

the ovarian stroma and its blood vessels, including renin gene expression, angiotensinogen and ANG II protein and ACE binding. Of particular importance when attributing a function to the stromal RAS, is the localisation of $\mathrm{AT}_{1 \mathrm{a}}$ receptor mRNA to the stroma adjacent to large follicles and corpora lutea, a finding previously reported in the bovine ovary (Schauser et al. 2001). The $\mathrm{AT}_{1 \mathrm{a}}$ receptor is viewed to elicit most of the cell growth and angiogenic properties of ANG II (Chung et al. 1998), and it is therefore likely that ANG II at this site influences processes such as blood flow, vascularisation and growth of developing follicles via this receptor. The finding that $\mathrm{AT}_{1 \mathrm{a}}$ receptor expression is reduced in HMZ (mRen-2)27 rats may be a result of the elevated ANG II in this strain compared with HTZ (mRen-2)27 and SD rats. This is supported by our finding that ovarian $\mathrm{AT}_{1}$ receptor mRNA is reduced in SD rats infused with ANG II, and by previous reports where high ANG II downregulates ANG II receptors in rat cultured granulosa cells (Pucell et al. 1988) and aortic vascular smooth muscle cells (Lassegue et al. 1995). 
Most of the components of the RAS were also localised to atretic follicles in both SD and transgenic (mRen-2)27 rats, suggesting that a distinct system may also exist within these follicles. The reason for the absence of renin protein immunolabelling in atretic follicles despite the presence of renin mRNA is unclear, but may indicate a translational modification in these follicles. Our finding that $\mathrm{AT}_{2}$ but not $\mathrm{AT}_{1 \mathrm{a}}$ receptor gene expression is located in atretic follicles is consistent with previous studies in rats (Tanaka et al. 1995, Obermuller et al. 1998), where the $\mathrm{AT}_{2}$ receptor was found to predominate in granulosa cells of follicles entering into atresia. This is consistent with the view that the $\mathrm{AT}_{2}$ receptor mediates apoptosis in some situations and opposes the proliferative effects of the $\mathrm{AT}_{1}$ receptor (Yamada et al. 1996, Chung et al. 1998).

It is well known that ANG II modulates ovarian steroidogenesis and corpora lutea formation (Yoshimura 1997, Speth et al. 1999, Vinson et al. 1999). In the present study, renin, ANG II and angiotensinogen immunolabelling and ACE binding were detected in both SD and (mRen-2)27 rat corpora lutea. A similar distribution for these RAS components has been reported previously in the rat (Lightman et al. 1988, Palumbo et al. 1989) and also in human (Palumbo et al. 1993) and bovine (Hayashi et al. 2000, Kobayashi et al. 2001) ovaries. Despite this evidence that some of the components of the RAS are located in corpora lutea, we were unable to detect either renin or angiotensin receptor gene expression, suggesting that renin and ANG II in corpora lutea may be sequestered from blood vessels or neighbouring cells. Previous studies in the rat have also reported angiotensin receptors to be absent in corpora lutea (Obermuller et al. 1998), while other studies have reported angiotensin receptors in cultured luteal cells (Pepperell et al. 1993) and renin mRNA in corpora lutea following gonadotrophin stimulation (Lightman et al. 1987). In other species the results are also inconsistent with angiotensin receptors reported to be both present (Hayashi et al. 2000, Schams et al. 2003) and absent (Schauser et al. 2001) in corpora lutea from cows and in low levels in pigs (Nielsen et al. 1995). The reason for the discrepancies between the studies is unclear but may relate to species variations and/or modulation of the RAS by gonadotrophins at various stages of the oestrus cycle (Loret de Mola et al. 1999).

In the present study, the degree of Ren-2 gene expression in (mRen-2)27 rats was associated with the abundance of the ovarian and circulating RAS. Transgenic (mRen-2)27 rats homozygous for the Ren-2 gene had higher expression of the ovarian RAS components and higher plasma prorenin and ovarian active renin levels than HTZ (mRen-2) 27 rats. Of interest was that overexpression of the ovarian RAS in (mRen-2)27 rats was associated with a reduction in the number of large antral and preovulatory follicles and litter size, and this was most obvious in HMZ (mRen-2)27 rats. It would therefore seem reasonable to argue that increased renin and angio- tensin in the ovary influences multiple processes within the ovary including follicular development, ovulation and subsequently birth rate. To further assess this concept, SD rats were infused with ANG II. The response of circulating and tissue RASs to ANG II infusion was verified by the observed reduction in active renin, which is expected as increased ANG II reduces renin production via a negative feedback mechanism. In addition, the infusion of ANG II into SD rats induced a similar reduction in large antral and preovulatory follicles as observed in HMZ (mRen-2)27 rats. The finding that ANG II infusion in SD rats reduced $\mathrm{AT}_{1 \mathrm{a}}$ receptors in the stroma but had no effect on $\mathrm{AT}_{2} \mathrm{mRNA}$, indicates that the reduction in large antral and preovulatory follicles may have resulted from ANG II via the $\mathrm{AT}_{1 \mathrm{a}}$ receptor modulating processes (such as blood flow, vascularisation and cell growth in the stroma) which are necessary for follicular growth. Furthermore, concentration-dependent effects of ANG II on oocyte viability have also been reported in rabbit ovaries perfused in vivo (Kuo et al. 1991), and this may partially explain why preovulatory follicles were found in fewer numbers in HMZ compared with HTZ (mRen-2)27 rats. A reason for the reduced litter size in homozygous (mRen-2)27 rats may be the known effects of ANG II on ovulation (Pellicer et al. 1988, Daud et al. 1990, Peterson et al. 1993). For instance, in mice with an enhanced ovarian RAS, a dose-dependent increase in expression of the angiotensinogen gene is associated with a reduction in ovulation rate (Hefler \& Gregg 2001). The reduction in large antral and preovulatory follicles described in the present study may also be explained by enhanced follicular apoptosis via the $\mathrm{AT}_{2}$ receptor. In cultured hamster follicles, ANG II treatment reduces the oestradiol to androgen ratio resulting in morphological changes in the theca interna that are observed in follicular atresia (Kitzman \& Hutz 1992). These findings are supported by the studies of Kotani et al. (1999) who reported in cultured rat granulosa cells that $\mathrm{AT}_{2}$ content increases in a time-dependent manner and parallels the progression of atresia.

The hypertension of the (mRen-2)27 rat and SD rats infused with ANG II may have also influenced follicular development and litter size. Vasoconstriction of ovarian vessels may alter follicular growth by compromising vessel patency, which is necessary for antral formation and enlargement and ovulation (Tsafriri 1995). Although the effect of hypertension on follicular development was not directly examined, our previous studies in the diabetic (mRen-2)27 rat indicate that amplification of the tissue RAS affects cell growth in the kidney and retina by a blood pressure independent mechanism (Kelly et al. 1998, Moravski et al. 2003). Further studies are required to determine if a similar effect occurs in the (mRen-2)27 rat ovary.

In summary, overexpression of the ovarian RAS in the transgenic (mRen-2)27 rat facilitated the characterisation of the tissue RAS in the stroma, atretic follicles and corpora 
lutea of the ovary. The localisation of $\mathrm{AT}_{1 \mathrm{a}}$ receptors to healthy follicles and $\mathrm{AT}_{2}$ receptors to atretic follicles suggests that these receptors play a differential role in balancing normal folliculogenesis. Increased expression of the RAS in the (mRen-2) 27 rat or by ANG II infusion in $\mathrm{SD}$ rats perturbs this balance resulting in a reduction in large antral and preovulatory follicles, and ultimately birth rate. Whether pharmacological blockade of the $\mathrm{AT}_{1}$ or $\mathrm{AT}_{2}$ receptors confers differential effects on folliculogenesis and atresia is not fully known, but such studies are warranted to further understand the role of the ovarian RAS in the normal ovary and pathologies such as polycystic ovary syndrome where overactivity of the circulating and ovarian RAS occurs (Yoshimura 1997).

\section{Acknowledgements}

The authors thank Miss Kassie Jaworski and Miss Suzanne Koerner for their expert technical assistance. The authors declare that there is no conflict of interest that would prejudice the impartiality of the study.

\section{References}

Bader M, Zhao Y, Sander M, Lee MA, Bachman J, Bohm M, Djavidani B, Peters J, Mullins JJ \& Ganten D 1992 Role of tissue renin in the pathophysiology of hypertension in TGR(mREN2)27 rats. Hypertension 19 681-686.

Berka JL, Stubbs AJ, Wang DZ, DiNicolantonio RN, Alcorn D, Campbell DJ \& Skinner SL 1995 Renin-containing Muller cells of the retina display endocrine features. Investigative Ophthalmology and Visual Sciences 36 1450-1458.

Berka JL, Kelly DJ, Robinson DB, Alcorn D, Marley PD, Fernley RT \& Skinner SL 1996 Adrenaline cells of the rat adrenal cortex and medulla contain renin and prorenin. Molecular and Cellular Endocrinology 119 175-184.

Bohm M, Lee M, Kreutz R, Kim S, Schinke M, Djavidani B, Wagner J, Kaling M, Wienen W, Bader M et al. 1995 Angiotensin II receptor blockade in TGR(mREN2)27: effects of renin-angiotensin-system gene expression and cardiovascular functions. Journal of Hypertension 13 891-899.

Bucci TJ, Bolon B, Warbritton AR, Chen JJ \& Heindel JJ 1997 Influence of sampling on the reproducibility of ovarian follicle counts in mouse toxicity studies. Reproduction and Toxicology 11 689-696.

Bunag RD 1973 Validation in awake rats of a tail-cuff method for measuring systolic pressure. Journal of Applied Physiology 34 279-282.

Chung O, Kuhl H, Stoll M \& Unger T 1998 Physiological and pharmacological implications of $\mathrm{AT}_{1}$ versus $\mathrm{AT}_{2}$ receptors. Kidney International 67 S95-S99.

Daemen MJ, Lombardi DM, Bosman FT \& Schwartz SM 1991 Angiotensin II induces smooth muscle cell proliferation in the normal and injured rat arterial wall. Circulation Research 68 450-456.

Daud AI, Bumpus FM \& Husain A 1990 Characterization of angiotensin I-converting enzyme (ACE)-containing follicles in the rat ovary during the estrous cycle and effects of ACE inhibitor on ovulation. Endocrinology 126 2927-2935.

Ekker M, Tronik D \& Rougeon F 1989 Extra-renal transcription of the renin genes in multiple tissues of mice and rats. PNAS $\mathbf{8 6}$ 5155-5158.
Fernandez LA, Twickler J \& Mead A 1985 Neovascularization produced by angiotensin II. Journal of Laboratory and Clinical Medicine 105 141-145.

Hayashi K, Miyamoto A, Berisha B, Kosmann MR, Okuda K \& Schams D 2000 Regulation of angiotensin II production and angiotensin receptors in microvascular endothelial cells from bovine corpus luteum. Biology of Reproduction 62 162-167.

Hefler LA \& Gregg AR 2001 Influence of the angiotensinogen gene on the ovulatory capacity of mice. Fertility and Sterility $\mathbf{7 5}$ 1206-1211.

Hirshfield AN \& Midgley AR Jr 1978 Morphometric analysis of follicular development in the rat. Biology of Reproduction 19 597-605.

Hodari AA, Smeby R \& Bumpus FM 1967 A renin-like substance in the human placenta. Obstetrics and Gynecology 29 313-317.

Kelly DJ, Wilkinson-Berka JL, Allen TJ, Cooper ME \& Skinner SL 1998 A new model of diabetic nephropathy with progressive renal impairment in the transgenic (mRen-2)27 rat (TGR). Kidney International 54 343-352.

Kelly DJ, Cox AJ, Tolcos M, Cooper ME, Wilkinson-Berka JL \& Gilbert RE 2002 Attenuation of tubular apoptosis by blockade of the renin-angiotensin system in diabetic Ren- 2 rats. Kidney International 61 31-39.

Kim S, Shinjo M, Tada M, Usuki S, Fukamizu A, Miyazaki H \& Murakami K 1987 Ovarian renin gene expression is regulated by follicle-stimulating hormone. Biochemical and Biophysical Research Communications 146 989-995.

Kitzman PH \& Hutz RJ 1992 In vitro effects of angiotensin II on steroid production by hamster ovarian follicles and on ultrastructure of the theca interna Cell Tissue Research 68 191-196.

Kobayashi S, Berisha B, Amselgruber WM, Schams D \& Miyamoto A 2001 Production and localisation of angiotensin II in the bovine early corpus luteum: a possible interaction with luteal angiogenic factors and prostaglandin $\mathrm{F}_{2 \alpha}$. Journal of Endocrinology 170 369-380.

Kotani E, Sugimoto M, Kamata H, Fujii N, Saitoh M, Usuki S, Kubo T, Song K, Miyazaki M, Murakami K \& Miyazaki H 1999 Biological roles of angiotensin II via its type 2 receptor during follicular atresia. American Journal of Physiology 276 E25-E33.

Kuo TC, Endo K, Dharmarajan AM, Miyazaki T, Atlas SJ \& Wallach EE 1991 Direct effect of angiotensin II on in-vitro perfused rabbit ovary. Journal of Reproduction and Fertility 92 469-474.

Lassegue B, Alexander RW, Nickenig G, Clark M, Murphy TJ \& Griendling KK 1995 Angiotensin II down-regulates the vascular smooth muscle $\mathrm{AT}_{1}$ receptor by transcriptional and post-transcriptional mechanisms: evidence for homologous and heterologous regulation. Molecular Pharmacology 48 601-609.

Lightman A, Deschepper CF, Mellon SH, Ganong WF \& Naftolin F 1987 In situ hybridization identifies renin mRNA in the rat corpus luteum. Gynecological Endocrinology 1 227-233.

Lightman A, Jones CL, MacLusky NJ, Palumbo A, DeCherney AH \& Naftolin F 1988 Immunocytochemical localization of angiotensin II immunoreactivity and demonstration of angiotensin II binding in the rat ovary. American Journal of Obstetrics and Gynecology 159 $526-530$.

Loret de Mola JR, Goldfarb JM, Hecht BR, Babbo CJ \& Friedlander MA 1999 Gonadotropins induce higher active renin levels in the follicular fluid of normal and hyperstimulated cycles. Gynecological Endocrinology 13 155-160.

Mendelsohn FA 1984 Localization of angiotensin converting enzyme in rat forebrain and other tissues by in vitro autoradiography using ${ }^{125}$ I-labelled MK351A. Clinical and Experimental Pharmacology and Physiology 11 431-435.

Moravski CJ, Kelly DJ, Cooper ME, Gilbert RE, Bertram JE, Shahinfar S, Skinner SL \& Wilkinson-Berka JL 2000 Retinal neovascularization is prevented by blockade of the renin-angiotensin system. Hypertension 36 1099-1104.

Moravski CJ, Skinner SL, Stubbs AJ, Sarlos S, Kelly DJ, Cooper ME, Gilbert RE \& Wilkinson-Berka JL 2003 The renin-angiotensin 
system influences ocular endothelial cell proliferation in diabetes: transgenic and interventional studies. American Journal of Pathology 162 151-160.

Mullins JJ, Peters J \& Ganten D 1990 Fulminant hypertension in transgenic rats harbouring the mouse Ren-2 gene. Nature 344 541-544.

Nielsen AH, Hagemann A, Avery B \& Poulsen K 1995 Differences in expression of angiotensin II receptors and renin in porcine and bovine ovaries. Experimental and Clinical Endocrinology and Diabetes 103 332-338.

Obermuller N, Schlamp D, Hoffmann S, Gentili M, Inagami T, Gretz N \& Weigel M 1998 Localization of the mRNA for the angiotensin II receptor subtype $2\left(\mathrm{AT}_{2}\right)$ in follicular granulosa cells of the rat ovary by nonradioactive in situ hybridization. Journal of Histochemistry and Cytochemistry 46 865-870.

Palumbo A, Jones C, Lightman A, Carcangiu ML, DeCherney AH \& Naftolin F 1989 Immunohistochemical localization of renin and angiotensin II in human ovaries. American Journal of Obstetrics and Gynecology 160 8-14.

Palumbo A, Pourmotabbed G, Carcangiu ML, Andrade-Gordon P, Roa L, DeCherney A \& Naftolin F 1993 Immunohistochemical localization of renin and angiotensin in the ovary: comparison between normal women and patients with histologically proven polycystic ovarian disease. Fertility and Sterility 60 280-284.

Pandey KN, Misono KS \& Inagami T 1984 Evidence for intracellular formation of angiotensins: coexistence of renin and angiotensin-converting enzyme in Leydig cells of rat testis. Biochemical and Biophysical Research Communications 122 1337-1343.

Pellicer A, Palumbo A, DeCherney AH \& Naftolin F 1988 Blockage of ovulation by an angiotensin antagonist. Science 240 1660-1661.

Pepperell JR, Nemeth G, Yamada Y \& Naftolin F 1993 The type 1 angiotensin-II receptor mediates intracellular calcium mobilization in rat luteal cells. Endocrinology 133 1678-1684

Peterson CM, Zhu C, Mukaida T, Butler TA, Woessner JF Jr \& LeMaire WJ 1993 The angiotensin II antagonist saralasin inhibits ovulation in the perfused rat ovary. American Journal of Obstetrics and Gynecology 168 242-245.

Phillips MI, Speakman EA \& Kimura B 1993 Levels of angiotensin and molecular biology of the tissue renin angiotensin systems. Regulatory Peptides 43 1-20.

Pucell AG, Bumpus FM \& Husain A 1988 Regulation of angiotensin II receptors in cultured rat ovarian granulosa cells by follicle-stimulating hormone and angiotensin II. Journal of Biological Chemistry 263 11954-11961.

Ryan JW 1967 Renin-like enzyme in the adrenal gland. Science 158 1589-1590

Ryan JW \& Johnson DC 1969 The renin-like enzyme of rabbit uterus. Biochimica et Biophysica Acta 191 386-396.

Schams D, Berisha B, Neuvians T, Amselgruber W \& Kraetzl WD 2003 Real-time changes of the local vasoactive peptide systems (angiotensin, endothelin) in the bovine corpus luteum after induced luteal regression. Molecular Reproduction and Development 65 57-66.

Schauser KH, Nielsen AH, Winther H, Dantzer V \& Poulsen K 2001 Localization of the renin-angiotensin system in the bovine ovary: cyclic variation of the angiotensin II receptor expression. Biology of Reproduction 65 1672-1680.

Sernia C, Davis M \& Thomas WG 1986 Purification of rat angiotensinogen. Preparations in Biochemistry 16 45-59.

Skinner SL, Lumbers ER \& Symonds EM 1968 Renin concentration in human fetal and maternal tissues. American Journal of Obstetrics and Gynecology 101 529-533.

Speth RC, Daubert DL \& Grove KL 1999 Angiotensin II: a reproductive hormone too? Regulatory Peptides 79 25-40.

Tanaka M, Ohnishi J, Ozawa Y, Sugimoto M, Usuki S, Naruse M, Murakami K \& Miyazaki H 1995 Characterization of angiotensin II receptor type 2 during differentiation and apoptosis of rat ovarian cultured granulosa cells. Biochemical and Biophysical Research Communications 207 593-598.

Thomas WG \& Sernia C 1990 The immunocytochemical localization of angiotensinogen in the rat ovary. Cell and Tissue Research 261 367-373.

Tsafriri A 1995 Ovulation as a tissue remodelling process. Proteolysis and cumulus expansion. Advances in Experimental Medicine and Biology 377 121-140.

Vinson GP, Saridogan E, Puddefoot JR, O'Mahony OA, Mahmood T \& Djahanbakhch O 1999 Renin-angiotensin systems and reproduction. Gynecological Endocrinology 13 56-70.

Wilkinson-Berka JL, Kelly DJ \& Gilbert RE 2001 The interaction between the renin-angiotensin system and vascular endothelial growth factor in the pathogenesis of retinal neovascularization in diabetes. Journal of Vascular Research 38 527-535.

Wilkinson-Berka JL, Kelly DJ, Rong P, Campbell DJ \& Skinner SL 2002 Characterisation of a thymic renin-angiotensin system in the transgenic m(Ren-2)27 rat. Molecular and Cellular Endocrinology 194 201-209.

Wulff C, Wiegand SJ, Saunders PT, Scobie GA \& Fraser HM 2001 Angiotensin during follicular development in the primate and its inhibition by treatment with truncated Flt-1-Fc (vascular endothelial growth factor Trap(A40)). Endocrinology 142 3244-3254.

Yamada T, Horiuchi M \& Dzau VJ 1996 Angiotensin II type 2 receptor mediates programmed cell death. PNAS 93 156-160.

Yoshimura Y 1997 The ovarian renin-angiotensin system in reproductive physiology. Frontiers in Neuroendocrinology 18 247-291.

Received in final form 14 October 2003 Accepted 17 October 2003 